\title{
小唾液腺唾石症の臨床病理学的検討
}

\author{
小林吉史・寺崎伸一郎・村 瀬 宏 \\ 田中俊一・亀山忠光・宮城巧
}

\section{A clinical and pathological investigation of sialolithiasis in minor salivary glands}

\author{
Yoshifumi Kobayashi $\cdot$ Shinichiro Terasaki $\cdot$ Hiroshi Murase \\ Shunichi TANaKa - Tadamitsu Kameyama - Takumi Mryagi
}

\begin{abstract}
We carried out a clinico-pathological examination in 7 cases of minor salivary gland sialolithiasis treated in the department of Oral and Maxillofacial Surgery, Kurume University, during the past 12 years (1977.1 1988.12). The results obtained were as follows; The average age of the patients was 63 years, with almost no difference between males and females. The MSGS in 3 cases appeared in the upper lip, 2 in the lower lip and 2 in the buccal mucosa. All these lesions were originated in the labial gland. Two stones and more, mostly 12 stones were found 6 cases. The stones ranged from 0.5 to $3 \mathrm{~mm}$ in diameter, mostly round in shape with lamella structure. Squamous metaplasia of the ductal epithelium was noted in 4 cases and oncocytes appeared in 2 cases. MSGS was observed in 7 (3.7\%) among 190 cases of "sialolithiasis", of which incidence is relatively high as compared with those reported in previous studies.
\end{abstract}

Key words: sialolithiasis (唾石症), minor salivary glands (小唾液腺), clinical and pathological (臨床・病理学)

緒

\section{言}

小唾液腺唾石症はまれとされ，その報告も少ない, 本邦ではほとんどが1例報告で3 15)，一施設での多数例 の報告はみられない．

今回われわ机は, 久留米大学医学部口腔外科で経験し た小唾液腺唾石症について, 臨床的, 病理組織学的に検 討を行ったのでその成績を報告する。

\section{研究対象ならびに研究方法}

研究対象は，1977年1月から1988年12月までの12年間 に久留米大学医学部口腔外科偟て処置され, 臨床的, 病

久留米大学医学部口腔外科学教室

(主任 : 龟山忠光教授)

The Department of Oral Surgery, Kurume University School of Medicine

(Chief: Prof. Tadamitsu Kameyama)

受付日：平成 2 年 7 月 25 日
理組織学的に小喠液腺喠石症と診断された 7 例である. 研究方法は, 外来あるいは入院カルテとX線より臨床 的に性・年湛別, 発生部位別, 自覚期間, 臨床症状なら びに臨床診断, 処置別などにつき検討した。 また, 病理 組織学的には切除された 5 例につき割断面を $\mathrm{HE}$ 染色 ならびにコッサ染色を施し, 鏡検し次の事項につき観察 した.

1. 唾石の大きさ, 数ならびに性状.

2. 唾石と導管との関係.

3. 腺房性状.

なお喠石の数については摘出した症例（No．2，5）で は摘出個数をもって, 残りの 5 例では残存せるブロック を半連続切片を作成し, 切片上の石灰化について病理組 織学的に算定した。

\section{研 究 結 果}

\section{1. 盬床的観察結果}

1) 性・年龄別

性・年路については, 男性 3 例, 女性 4 例で性差はな 


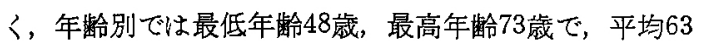
歳と高い年龄にみられた（表1）。

2 ）発生部位別

発生部位別は上唇部 3 例，頓粘膜部 2 例，下唇部 2 例 であった（表2）。なお頓粘膜部の 2 例は，上・下顎小 臼霜部相当の位置で口唇腺に由来するものであった。

3) 自覚期間

自覚期間は 4 例は 1 か月以内に来院し, すべて 1 年以

表 1 性・年踰別

\begin{tabular}{c|c|c|c}
\hline 年 粭 & 男 性 & 女 性 & 計 \\
\hline $40 \sim$ & 0 & 1 & 1 \\
$50 \sim$ & 0 & 2 & 2 \\
$60 \sim$ & 1 & 0 & 1 \\
70 以上 & 2 & 1 & 3 \\
\hline 計 & 3 & 4 & 7 \\
\hline
\end{tabular}

（久大医口外 1977. 1 1988. 12）

表 2 発生部位別

\begin{tabular}{c|c}
\hline 部 位 & 例 数 \\
\hline 上 唇 部 & 3 \\
頓粘膜部 & 2 \\
下 唇 部 & 2 \\
\hline 計 & 7 \\
\hline (久大医口外 1977.1 1 1988.12)
\end{tabular}

表 3 自覚期間

\begin{tabular}{c|c}
\hline 自覚期間 & 例 数 \\
\hline 7 日以内 & 2 \\
8 日〜 $\sim$ か月 & 2 \\
2 か月 1 年 & 3 \\
\hline 計 & 7 \\
\hline
\end{tabular}

（久大医口外 1977.1 1988. 12）
内であった（表了）。

4) 臨床症状ならびに臨床診断（表 4).

臨床症状が可動性の瘇瘤で白色の硬固物を触知した 3 例は，小唾液腺俨石症亡診断されていた。このうち， $\mathrm{X}$ 線不透過像を認め得たものは 1 例のみであった（写真 1). 腫脹と疼痛に排膿を認めた 3 例では，小喠液腺炎 2 例，粘液垔胞 1 例であった. 牫りの 1 例は可動性の腫 瘤で多形性腺腫と診断されていた。

\section{5) 処置別}

処直は健康部を含めて周囲より切除されたものが 5 例，唾石の摘出が 2 例であった。

\section{6）唾石症の部位別頻度}

同期間に当科で経験した唾石症は紷数 190 例で，その 発症部位別は小唾液腺㗭石症は7例で，全体の3.7\% に 相当していた（表5）.

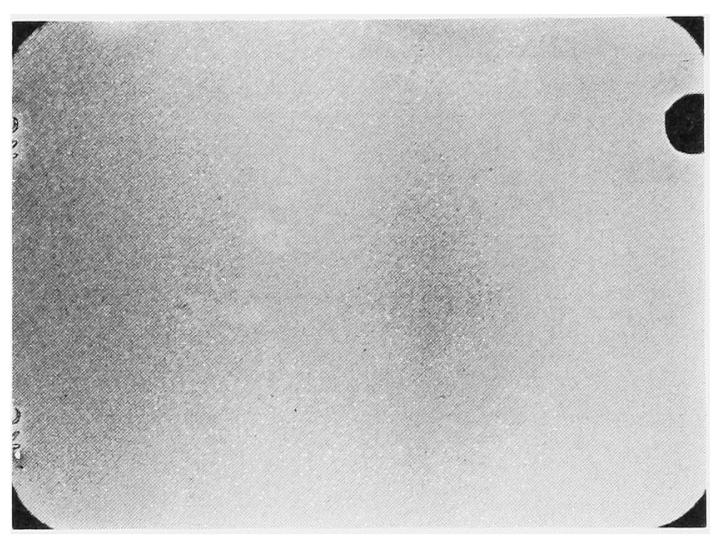

写真 1 症例 5 のX線像

表 5 唾石症総数と部位別频度

\begin{tabular}{c|c|c}
\hline & 例 数 & $\%$ \\
\hline 顎下 腺 & 180 & 94.7 \\
耳下 腺 & 3 & 1.6 \\
小硂液腺 & 7 & 3.7 \\
\hline 計 & 190 & 100 \\
\hline (久大医口外 1977.1 1 1988. 12)
\end{tabular}

表 4 臨床症状ならびに臨朱颜断

\begin{tabular}{|c|c|c|c|c|c|c|c|}
\hline 臨休診断（症例数） & 盘 瘤 & 腫 脹 & 可動性 & 硬固物 & 排 膿 & 疼 痛 & $\begin{array}{c}\mathrm{X} \text { 線 } \\
\text { 不透過像 }\end{array}$ \\
\hline 小哖液腺唾石症 (3) & 3 & 0 & 3 & 3 & 0 & 0 & 1 \\
\hline 小唾液腺炎 （2） & 0 & 2 & 0 & 0 & 2 & 2 & 0 \\
\hline 粘液葆胞 & 0 & 1 & 1 & 0 & 1 & 1 & 0 \\
\hline 多形性腺尰 $\quad$ (1) & 1 & 0 & 1 & 0 & 0 & 1 & 0 \\
\hline
\end{tabular}

(久大医口外 1977.1～1988.12) 
表 6 唾石の数・性状

\begin{tabular}{c|c|c|c|l}
\hline 症例番号 & 数 & 大きさ $(\mathrm{mm})$ & 形 態 & 構 造 \\
\hline 1 & 2 & 1 & 不整形 & 層状構造 \\
2 & 1 & 3 & 不整形 & \\
3 & 2 & 0.5 & 不整形 & 層状構造 \\
4 & 2 & 1 & 球 形 & \\
5 & 12 & $0.5 \sim 2$ & 不整形 & 層状構造 \\
6 & 4 & 1 & 球 形 & 層状構造 \\
7 & 9 & $1 \sim 2$ & 球 形 & 層状搆造 \\
\hline
\end{tabular}

（久大医口外 1977. 1 1988. 12）

表 7 病理組織学的所見

\begin{tabular}{|c|c|c|c|}
\hline & & 有 & 無 \\
\hline 潄石 & 導管内 & 2 & 3 \\
\hline \multirow{2}{*}{ 並管 } & 桩 張 & 3 & 2 \\
\hline & 扁平上皮の化生 & 4 & 1 \\
\hline \multirow{3}{*}{ 腺房 } & 炎症の有無 & 4 & 1 \\
\hline & オンコサイトの出現 & 2 & 3 \\
\hline & 荌 縮 & 2 & 3 \\
\hline
\end{tabular}

（久大医口外 1977.1 1988. 12）

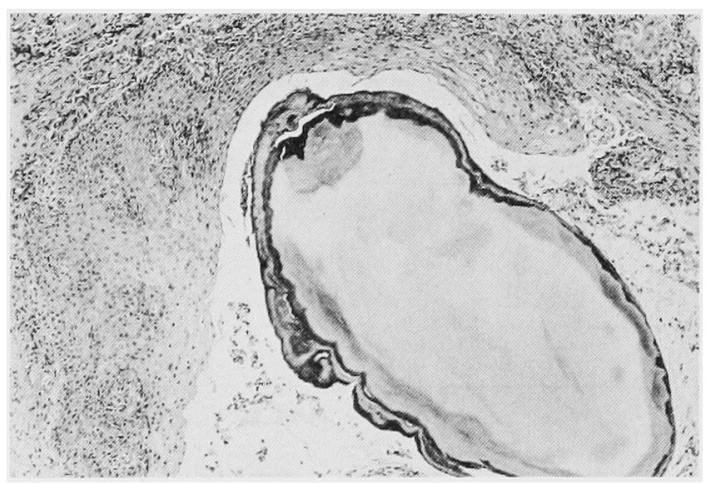

写真 2 病理組織学的所見 (HE 染色， $\times 20)$

\section{2. 病理組織学的検討結果}

1）唾石の数，大きさおよび性状（表 6)

唾石の数は 2 個認められたものが 3 例， 1 個認められ たものが 1例で最高は12個であった，大きさは 0.5 から $3 \mathrm{~mm}$ 大の大きさで多くが $1 \mathrm{~mm}$ 以内であった。形態 は球形を示すものが32個中 27 個で，その他に不整形のる

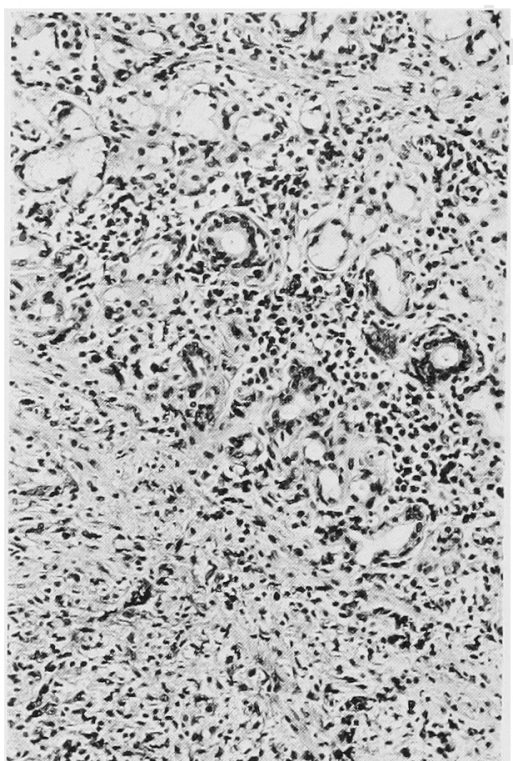

写真 3 病理組織学的所見 (HE 染色, $\times 50$ )

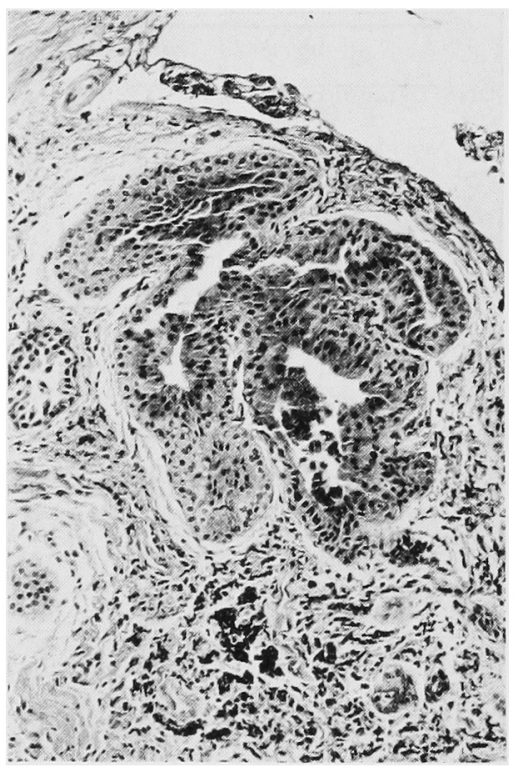

写真 4 病理組織学的所見 (HE 染色, $\times 100$ )

のを認めた，構造は32個中29個が凮状構造を呈し，2 個 が均質罡檴造であった。

2) 醀石と導管との関係（表 7 ）

切除による 5 例での唾石と渞管との関俰では，整石が 尊管内に認められたのは 2 例であった，導管については 拡張しているものが 3 例，その導管上皮に扁平上皮化生 が認められたものが 4 例であった（写真 2 ）。 


\section{3) 腺房の性状（表 7)}

腺房については炎症性細胞浸潤を認めるものが 4 例 (写真 3), オンコサイト様変化 (写真 4 ) 户腺房の萎縮 を認めるものがそれぞれ2例に認められた。

\section{考察}

唾石症は喠液腺の腺体内あるいはその導管のなかに結 石を生ずる疾患で，その部位別発症頻度としては， Rauch ら ${ }^{1)}$ によると, 㴿下腺 $92 \%$, 耳下腺 $6 \%$, 舌下腺 および小唾液腺が $2 \%$ とされ，小唾液腺唾石症はまれ之 されている，その 1 例報告は古く，1864年に $\mathrm{Papin}^{16}{ }^{16}$ が 軟口蓋に発症した小唾液腺唾石症を報告している。その 後症例報告が散見されるに過ぎず, Hobkirk ${ }^{17)}$, Pullon ら ${ }^{18)}$ による文献上での集計報告がなされ，きわめてまれ のものとされていた。ところが, Jensen ら ${ }^{19}$ が，1979年 に口腔病理研究所の標本を12年間にわたって再検討を行 ったところ，47例の小唾液腺唾石症がみられたと報告し て以来, Anneroth $5^{20)}$, Yamane ${ }^{21)}$ のそれぞれ40例, 76例の同一機関内での集計による, 詳細な臨床的病理組 織学的検討結果が報告され，まれな疾患ではないとされ るようになってきた。しかし，本邦では1933 年に赤坂 ら゙)が口蓋に発症したのを報告して以来, わ扏れが渉 猟しえた範囲では，25例の報告がみられるの久である。 しかもこれらの報告は, 最近急増しほとんどが症例報告 である.

そこで，今回われわれは，臨床的病理組織学的に小唾 液腺唾石症と診断された 7 例について検討を行った。 そ の診断は唾液腺の存在する粘膜下に白色の硬固物を触知 するか，X線撮影で不透過像を認めたもの，また切除後 の切片で病理組織学的に塊状の石灰化物を諰めたものを 唾石症とした。

これは，同期間における当科での唾石症190例の3.7\% に相当し，Rauchらの報告より高かったまた部位別で は，顎下腺が 180 例 $(94.7 \%)$ で最も多く，ついで小唾 液腺唾石症の 7 例で，耳下腺が 3 例 $(1.6 \%)$ 之従来の 報告に対し，順位が逆転していた。

われわれの検討結果を Jensen ら, Anneroth ら， Yamane らの多数例での検討結果と比較した。

発生年柃については, Jensen らは27〜80歳, 平均58.4 歳, Anneroth らは 9 82歳, 平均 54. 5 歳, Yamane ら は12 87歳, 平均48.5 歳と報告し, 本邦に拈いては, 浅 田らによる本邦報告例の集計結果によると，22７7歳， 平均54.3歳上変わりはなかったが, 自験例では48〜73 歳, 平均63歳之高い年路婂々られた。

性別発生頻度については, Anneroth らの報告による 之, 男性29例, 女性 20 例と男性に多く, 逆に Jensen 万 は男性20例，女性26例之女性に多い。本邦に叔いては浅 田らによると，男性14例，女性 5 例と男性に多い。自験
例では男性 3 例，女性 4 例と性差はなかった。

発生部位では，いずれの報告 ${ }^{18-21)}$ あるいは集計報告 例15)をみても上唇部および煩粘膜部に好発し，しかも煩 粘膜部はわれわれの報告同様，耳下腺乳頭部上り前方部 で，口唇腺他起因するものがほとんどである。その他の 部位としては口蓋部, 下唇部, 舌, 歯肉頓移行部などの 報告例がみられるが症例は少ない，自験例では，上唇部 3 例, 煩粘膜部 2 例, 下唇部 2 例と上唇部に多かった。 上唇部および頓粘膜部が好発部位である理由として, Jensen らは外傷，導管の形態などの局所的要因や唾液 の性状などの生化学的要因も関与している可能性がある のではないかと述べている。自験例での煩粘膜部に発生 したもの 2 例とも小臼歯相当部より前方部に認められ， いずれも口唇腺に由来するもので，その原因として何ら かの歯牙による外傷が大きな要因をなしているのではな いかと考光ている。

自覚期間については, Jensen らは不明22例を除くを1 か月以内の 7 例, $1 \sim 6$ か月 4 例, Anneroth らは, 不明 21 例を除くと, $1 \sim 6$ か月 13 例, $1 \sim 3$ 年 9 例であった としている。浅田らは，不明 1 例除き，1か月以内が 8 例， $1 \sim 6$ か月 5 例， $1 \sim 3$ 年 5 例と報告している. その多くが早い時期俘診しており，自験例でも 1 か月 以内が 4 例で, すべて 1 年以内であった。滝川ら ${ }^{22}$ は㖽 下腺唾石症の自覚期間について平均 6 年 7 か月であった 之報告しているのをみると小唾液腺唾石症は自覚期間が 短く、口腔前方部に好発することにより早期に自覚し受 診していることがわかる.

臨床症状としては, 粘膜下に無痛性で可動性を有する 腫瘤としてみられることが多く, 炎症を伴った場合, 疼 痛や排膿も認めら机ている。 Anneroth らによると炎症 症状を伴った症例が 49 例中 8 例に認められたとしてい る。浅田らは，19例中 3 例に認めている。大唾液腺唾石 症の場合, 唾腫や唾仙痛といった特徵的な症状を呈する が, 小唾液腺唾石症の場合, 特徵的な臨床症状が必ずし も認められないそそのため, 臨床診断が容易ではない。 それは，唾液腺腫瘍あるい:唾液腺炎との䛦断で切除さ れているものが多いことからもらなずける. Anneroth らは, 粘液整胞 21 例, 唾液腺腫瘍 12 例, 異物 7 例, 小唾 液腺炎 6 例としている。 また，本症と診断しにくいもの の1つとして硬固物を触れてもX線撮影を行らことによ り唾石と思わせる不透過像が認めら机ないことがあげら れる。山部ら ${ }^{23)}$ による集計結果もとれを示している。す なわち，X線不透過像を認められたものは，25例中 9 例 であり, 硬固物を触知するにもかかわらす楾不透過像 を認めなかったものは11例認められたとしている、自験 例でも, 可動性の腫瘤を示すものが 4 例, その5ち 3 例 に硬固物が触知されたにもかかわらず,この3 例中X線 で不透過像を認められたものは1例のみであった。

処置については, Yamane らの例でも多くは健康部圭 
含めて周囲より切除されている. 自験例では, 切除され たものが 5 例, 唾石の摘出のみが 2 例で, 摘出後, 腫瘤 の消失をみて扣り，導管内唾石と同様，唾石の摘出で治 瘉することを示している。

唾石の数は, Jensen や山嵩らの報告をみると 1 個の症 例が多く, 複数の症例必認められる. 自験例では, 7 例 中 2 個以上認められたものが 6 例に認められた.

唾石の大きさは, Jensen らは $1 \sim 3 \mathrm{~mm}$ のものが多い としている. 山挐らは極小, 米粒大, 小豆大, 大豆大, $15 \times 13 \times 12 \mathrm{~mm}$ としている. 自験例では， $0.5 \sim 3 \mathrm{~mm}$ であり, Jensen らの結果と一致していた。 このことから も唾石とのものが小さく触知困難であるために臨床診断 が難しいものと思われる。このため, 診断を確実に行う ためには注意深い触診とX線撮影条件の確立が必要と思 われ，その他エコーなどの画像診断も今後取り入れて行 くべきではないかと考えている。

唾石の形態は，球状を示すものが32個中15個で，他は 不整形を示すむのであった.

唾石の構造は, 層状構造を示すものが多いとされてお り, 自験例では32個中12個に層状構造を認め, 他は均質 無構造であった。このように，小唾液腺唾石症では，唾 石が小さく，大唾液腺棰石とその成長過程を異にするの かもしれない。

小唾液腺唾石 は導管内に存在することが多く, Anneroth らは49例中39例に, Jensen らは41例中35例に 認めたとしている. また導管は抎張していることが多 く，その導管上皮の扁平上皮化生を Anneroth らは，39 例中26例に認めている. 自験例で切除による 5 例では, 2 例に導管内に唾石を認め，また導管が抎張しているも のが 3 例に認められ，その導管上皮の扁平上皮化生も 4 例に認められた。

腺房の所見では，Jensen, Yamane らの報告によると 種々の程度の炎症性細胞浸潤や腺房の萎縮などを呈する ものが多いとしている. 自験例では, 炎症性細胞浸潤を 4 例に, 腺房の萎縮を 2 例に認めた。 その他, オンュサ イトの出現も 2 例に認められた。

小唾液腺唾石症が本邦における報告例が少ない理由と して考えられることは，大唾液腺唾石症のように特徽的 な臨床症状を示さず，さまざまな臨床症状を示すことや 触診時に, 唾石そのものが小さく硬固物を触知不可能な 場合があることなどが考えられる，また，触診時に硬固 物を触れるにもかかわらずX線にて不透過像を確認でき ないことが多いためと考えられる。そのうえ, 病理組織 学的検査がなされていなかったり，あるいは摘出物が 小さいために連続薄切標本による検査がなされず，唾石 そのものが薄切されていないことなどの理由が考えられ る. その他, 異物の排泄機構により, 自然治瘉し来院さ れていない症例もあるのではないかと考えられる。さら に, 多くの症例を追加し, 大唾液腺唾石との形態学的,
物理学的検討比較を行ってみたい

\section{ま とめ}

われわれは，1977年 1 月から1988年12月までの12年間 に久留米大学医学部口腔外科を受診し，小唾液腺唾石症 と診断された 7 例につき, 臨床, 病理組織学的検討を行 い次のような結果を得た

1. 同期間の唾石症190例で, 小唾液腺唾石症 7 例(3.7 \%)に相当していた.

2. 発生年齢では平均 63 歳と高かった。

3. 性別発生頻度では性差はなかった。

4. 発生部位では上唇部 3 例, 煩粘膜部および下唇部 がそれぞれ 2 例ですべてロ唇腺由来であった。

5. 病理組織学的に唾石の数では， 1 個が 1 例，その 他は 2 個以上で最高12個であった。 また，大きさは 0.5 から $3 \mathrm{~mm}$ 大範囲で, 形態は球形で層状構造を示すもの が多かった，導管上皮に扁平上皮化生が 4 例に，オンコ サイトの出現が 2 例に認められた。

本論文の要旨は, 第34回日本口腔外科学会総会（平成 元年10月，郡山市）に拈いて発表した。

\section{引用 文 献}

1) Rauch, S. and Gorlin, R.J.: Thoma's Oral Pathology. 6th Ed, Mosby Co, St Louis, 1970, p 997-1003.

2) 石川梧朗, 秋吉正豊 : 口腔病理学 II. 永末書店, 京都, 1978，425-429頁.

3）赤坂東九郎：口蓋腺並臼菌腺部に発生したる唾 石の刺激による口腔癌の 1 例。臨床齿科 52 : 259-263 1933.

4）川原秀樹, 亀山忠光, 他 : 小唾液腺唾石症の 1 例. 日口外誌 25：335-340 1979.

5）内堀健二, 中山桂二, 他 : 小唾液腺に生じた唾 石症の 1 例。口科誌 28: 63-74 1979.

6）長山 勝, 中田茂樹, 他: 唾石を伴った表在性 化膿腺炎と思われる 1 症例. 日口外誌 25：8538571979.

7）伊達岡陽一, 石川武憲, 他 : 小唾液腺（頓腺） に発生した唾石症について一その1. 症例と文献 的考察一。 日外誌 27: 1129-1137 1981.

8）堀稔, 横川 正, 他: 煩粘膜に生じた小唾 液腺唾石症の 2 例。日口外誌 28：264-271 1982.

9) 中野 久, 永山清則, 他：小唾液腺唾石を伴っ た腺性口唇炎の 1 例（抄）。日口外誌 28：1360 1982.

10）玉城廣保，山田博基, 他：小唾液腺唾石症の 2 例 (抄). 日口外誌 29: 1152-1153 1984 .

11）輔木 徹, 斉藤健一, 他 : 上唇に生じた小唾液 
腺唾石症の 1 例。 日口外誌 30：1501-1504 1984.

12) 大木秀郎, 瀧川富雄, 他：上唇部に生じた小唾 液腺唾石症の 1 例（抄）。日外誌 $30 ： 2080$ 1984.

13）阿部廣幸, 関口英行, 他：小唾液腺唾石症の 3 例。口科誌 34：727-735 1985.

14）森家祥行，村上賢一郎，他：下唇に生じた小唾 液腺唾石症の 1 例 (抄). 日口外誌 33：2072081987.

15）浅田沈一，中川洋一，他：小唾液腺㗲石症一自 験症例と文献的考察一 日口外誌 35：436-443 1989.

16) Papin, D.: Salivary calculus. Dent Cosmos 6: 136 1864-1865.

17) Hobkirk, J.A.: Sialolithiasis of minor salivary gland; A case report and review of the literature. Dent Pract 20: 213-214 1970.

18) Pullon, P.A. and Miller, A.S.: Sialolithiasis of accessory salivary glands; Review of 55 cases. J Oral Surg 30: 832-834 1972.

19) Jensen, J.L., Howell, F.V., et al.: Minor salivary gland calculi; A clinicopathologic study of forty-seven new cases. Oral Surg 47 : 44-50 1979.

20) Anneroth, G. and Hansen, L.S.: Minor salivary gland calculi; A clinical and histopathological study of 49 cases. Int J Oral Surg 12: 80-89 1983.

21) Yamane, G.M., Scharlock, S.E., et al.: Intraoral minor salivary gland sialolithiasis. J Oral Med 39: 85-90 1984.

22) 渲川富婎, 藍原健児, 他：顎下腺内唾石症につ いて。 日大迷学 44: 159-173 1970.

23）山知康之, 坂本栄一, 他：上唇に発生した小喠 液腺唾石症の 1 例一その唾石の構造 - 組成分析 について一 日口外誌 35：2596-2605 1989. 